\title{
Anak Punk Jalanan di Jambi dalam Perspektif Hukum Pidana
}

\author{
Dedy Syaputra ${ }^{*}$, Sartika Lia Apriana ${ }^{2}$ \\ ${ }^{1,2}$ Fakultas Hukum Universitas Batanghari \\ Jalan Slamet Riyadi Broni Kota Jambi Telp: (0741) 65351 \\ *Correspondence email: jambidedy05@gmail.com; Liaapriliana777@gmai.com
}

\begin{abstract}
Abstrak. Fenomena anak jalanan di Jambi ini jelas membuktikan sebuah fakta bahwa tidak terpenuhinya hak-hak anak baik oleh orang tua, masyarakat, maupun negara. Disisi lain, adanya variasi dan jenis profesi dan sektor pekerjaan yang tidak resmi (formal) di kota membuat kehidupan kota lebih beragam dari sudut jenis pekerjaan yang tersedia. Inilah merupakan salah satu faktor yang membuat tiap individu termasuk para anak yang seyogiyanya bersekolah malah tertarik untuk mencari nafkah, dan kasus yang lebih unik lagi adalah di kota-kota, jenis pekerajan untuk seusia remaja juga tersedia banyak. Inilah sebabnya mengapa anak jalanan lebih sering dijumpai di kota daripada di desa. Jika diperhatikan dengan seksama, titik lokasi berkumpulnya anak jalanan tersebut sangat berbahaya. Selain mengganggu ketertiban dan kenyamanan orang lain, juga dapat membahayakan dirinya sendiri dan memberi peluang untuk tindak kekerasan. Bahkan anak jalanan itu sendiri berpotensi menjadi kriminil seperti mengompas teman-temanya atau individu yang lainnya yang lebih lemah, pencurian kecil-kecilan, dan pemakaian bahkan perdagangan obat-obatan yang tergolong zat yang berbahaya bagi kesehatan.Untuk mendekati persoalan ini, maka peneliti menggunakan paradigma kualitatif dari perspektif hokum pidana. Adapun temuan dari hasil penelusuran data di lapangan diperoleh hal sebagai berikut: (1) Faktor penyebab banyaknya anak jalanan di kota Jambi adalah dikarenakan tidak terpenuhinya kebutuhan fisik dan psikis anak, kemudian, karena keinginan pribadi dari anak jalanan itu sendiri dan faktor lingkungan. (2) Dampak persoalan pidana yang dapat mengarah kepada tindakan kriminal dari adanya anak jalanan adalah: munculnya problematika sosial baru, terganggunya ketertiban kota, dan mengancam keselamatan dan keamanan warga masyarakat disekitarnya.
\end{abstract}

Kata kunci: punk; anak jalanan; perspektif hokum; pidana

\begin{abstract}
This phenomenon of street children in Jambi clearly proves a fact that the rights of children are not fulfilled by parents, society, or country. On the other hand, the variety and types of unofficial professions and occupational sectors in the city make city life more diverse from the angle of the types of jobs available. This is one of the factors that makes each individual including the children who attend school even interested in making a living, and the more unique case is in cities, the type of pecerajan for the age of adolescence is also widely available. This is why street children are more common in the city than in the village. If carefully observed, the point where street children gather is very dangerous. In addition to disturbing the order and comfort of others, it can also harm itself and provide opportunities for acts of violence. Even street children themselves have the potential to become criminous such as compressing their friends or other weaker individuals, petty theft, and the use of even trafficking drugs that are classified as substances that are harmful to health. To approach this issue, researchers used a qualitative paradigm from a criminal perspective. The findings of the data search results in the field are obtained as follows: (1) The causative factor of the number of street children in Jambi city is due to the unmet physical and psychic needs of the child, then, because of the personal desire of the street children themselves and environmental factors. (2) The impact of criminal problems that can lead to criminal acts from the appearance of street children are: the emergence of new social problems, disruption of city order, and threatening the safety and security of the citizens of the surrounding communities.
\end{abstract}

Keywords: punk; street children; hokum perspective; Criminal

\section{PENDAHULUAN}

Remaja merupakan aset generasi penerus bangsa mendatang yang sangat penting. Bisa disimpulkan bahwa baik buruknya masa depan sebuah bangsa ditentukan oleh generasi pengembanya di masa yang akan datang. Dalam hal ini ditangan para remaja-lah tergenggam masa depan suatu bangsa. Wajar bila setiap individu yang mature yang menyadari masalah ini mempersiapkan strategi pendidikan yang baik untuk anak-anak mereka. Tidak hanya itu, proses tumbuh kembang pun sangat diperhatikan dalam rangka mengarahkan dan membimbing mereka menuju tujuan yang diinginkan.Maka pehatian terhadap hak-hak remaja menjadi suatu keharusan direalisasikan, yaitu membentuk pemuda generasi bangsa yang bermutu.

Akan tetapi, sekarang ini, remaja yang idealnya mendapat kasih sayang dari lingkungannya telah melangkah jauh menjadi anak jalanan.Situasi ini muncul seiring dengan perubahan zaman dan budaya yang telah bergeser semakin terdegradasi. Pergeseran nilai dan sikap remaja telah terjadi dan seakan-akan sulit untuk dibendung. Hal ini terjadi karena derasnya arus informasi yang tanpa batas dan juga adanya masalah dalam lingkungan internal keluarga dan eksternal masyarakat yang komitmenya sudah mengalami penyusutan terhadap norma dan nilai.

Kuantitas anak jalanan semakin bertambah meningkat dari tahun ke tahun, banyak hal yang menjadi penyebab bagi seorang remaja untuk terjun atau bergabung menjadi anak jalanan, salah satunya adalah masalah rendahnya 
ekonomi yang tentu saja bukan masalah baru di Indonesia, khususnya di Provinsi Jambi ini. Menurut data yang telah dirilis oleh Badan Pusat Statistik (BPS) Provinsi Jambi tahun 2008 telah dikemukakan bahwa jumlah penduduk miskin perkotaan hingga bulan Juni 2010 tercatat sebesar 47,11 persen dari 446.872 jiwa. ${ }^{1}$ Akan tetapi, pada dasarnya tidak sekedar masalah ekonomi dan kemiskinan yang menyebabkan anak jalanan turun kejalan, melainkan keinginan mereka sendiri untuk merasakan freedom tanpa banyak kekangan dari orang tua dan lingkungan sekitar mereka berada. $^{2}$

Ada sebagian kecil dari anak jalanan menganggap bahwa mereka lebih senang untuk bekerja dan mencari uang untuk senang-senang dan bebas dari aturan yang dalam pemahaman mereka dirasakan mengekang. Apalagi mereka mendapatkan uang yang kadangkala kurang lebih Rp. 20.000,- sampai Rp. 100.000,- per hari dari mengamen. Akibatnya dapat ditebak, anak jalanan menjadi malas diajak ke lingkungan normal seperti pada umumnya anak seusia mereka, misalnya bersekolah dan mendapatkan perhatian sewajarnya.Tetapi pada kenyataanya mereka justeru lebih menikmati hidup dijalanan.

Namun demikian, walaupun begitu jalanan bukanlah tempat yang baik bagi anak-anak dan remaja.Karena dengan mudah masuknya pengaruh negatif seperti narkoba, kriminalitas; merampok dan mencopet merasuk kedalam prilaku anak jalanan yang hidupnya dijalanan tersebut.

Indiviu perlu untuk mengetahui membedakan adanya perilaku menyimpang yang tidak disengaja dan yang disengaja.Diantaranya karena si pelaku kurang memahami aturan-aturan yang ada.Padahal perilaku yang menyimpang yang disengaja, bukan karena individu tidak mengetahui aturan.Situasi yang relevan untuk memahami bentuk perilaku tersebut, adalah mengapa seseorang melakukan penyimpangan, padahal pada prinsipnyaia tahu apa yang dilakukan melanggar aturan. Becker mengatakan bahwa tidak ada alasan untuk mengasumsikan hanya mereka yang menyimpang mempunyai dorongan untuk berbuat demikian.Hal ini disebabkan karena pada dasarnya setiap manusia pasti mengalami nyimpang dan dorongan untuk melanggar pada situasi tertentu, tetapi mengapa pada kebanyakan orang tidak menjadi kenyataan yang berwujud tukan perilaku penyimpangan, sebab orang dianggap normal biasanya dapat menahan diri dari dorongan-dorongan untuk menyimpang. ${ }^{3}$

Kegiatan sosialisasi terjadi dalam kehidupan sehari-hari melalui interaksi sosiai dengan menggunakan media atau lingkungan sosial tertentu. Oleh sebab itu, kondisi kehidupan lingkungan tersebut akan sangat mewarnai dan mempengaruhi masukan dan wawasan yang diserap. Salah satu variasi dari teori yang menjelaskan kriminalitas di daerah perkotaan, bahwa beberapa tempat di kota mempunyai sifat yang kondusif bagi tindakan kriminal oleh karena lokasi tersebut mempunyai karakteristik tertentu, misalnya Eitzen mengatakan tingkat kriminalitas yang tinggi dalam masyarakat kota pada umumnya berada pada bagian wilayah kota yang miskin, dampak kondisi perumahan di bawah standar, overcrowding, derajat kesehatan rendah dari kondisi serta komposisi penduduk yang tidak stabil. ${ }^{4}$

Tulisan inipun dilakukan di salah satu daerah pinggiran kota yaitu di Pondok Pinang Jakarta Selatan tampak ciri-ciri seperti disebutkan Eitzen diatas.Sutherland dalam Eitzen (1986) beranggapan bahwa seorang belajar untuk menjadi kriminal melalui interaksi. Apabila lingkungan interaksi cenderung devian, maka seseorang akan mempunyai kemungkinan besar untuk belajar tentang teknik dan nilai-nilai devian yang pada gilirannya akan memungkinkan untuk menumbuhkan tindakan kriminal.Menurut Paul B. Horton, penyimpangan sosial memiliki enak ciri-ciri antara lain sebagai berikut: ${ }^{5}$

1. Bentuk penyimpangan harus dapat didefinisikan Tidak ada perbuatan yang terjadi begitu saja dinilai atau dapat dianggap sebagai perilaku menyimpang;

2. Tindakan menyimpang bukanlah hanya dari ciri tindakan yang dilakukan orang, melainkan akbiat dari adanya peraturan dan penerapan sanksi yang dilakukan oleh orang lain terhadap perilaku tersebut;

3. Tindakan penyimpangan bisa diterima atau bisa juga ditolak tidak semua perilaku menyimpang negatif, ada juga yang diterima bahkan dihormati seperti orang genius yang menyampaikan pendapat baru yang bertentangan dengan pendapat umum. Sedangkan perampokan, pembunuhan, dan menyebarkan teror bom atau gas beracun termasuk penyimpangan yang ditolak masyarakat;

4. Tindakan penyimpang relatif dan penyimangan mutlak Di dalam satu masyarakat tidak ada seorang pun yang termasuk dalam kategori sepenuhnya penurut (konformis) ataupun spenuhnya. Pada dasarnya semua orang normal pasti pernah melakukan tindakan yang menyimpang dari norma-norma yang berlaku, namun terdapat batas-batas tertentu yang bersifat relatif untuk setiap orang. Seperti halnya tidak ada seorang pun yang setiap perbuatannya menyimpan di norma-norma yang berlaku. Perbedaannya ada di seberapa sering (frekuensi) dan

${ }^{1}$ Data statistik kota Jambi. Data tersebut penulis peroleh berdasarkan hasil wawancara penulis dengan petugas BPPS, Bapak Rahmat pada tanggal 15 Juli 2020

${ }^{2}$ http: //yayasan - kksp . blogspot. com / 2007 / 08 / anak-jalanan-harus-diberi-pendidikan.html. Diakses pada tanggal 10 Juli 2020 pada pukul 14:00 WIB

${ }^{3}$ Soerjono Soekanto, Sosiologi Suatu Pengantar (Jakarta: Raja Grafindo, 1988), hlm. 26

${ }^{4}$ Stanlen D. Eitzen, Social Problems (Sydney: Allyn and Bacon Inc, 1986), hlm. 400

${ }^{5}$ Ibid. 
kadarpenyimpangannya saja. Meskipun ada orang yang sering sekali melakukan penyimpangan sosial (penyimpang mutlak), lambat laun dia juga harus berkompromi dengan lingkungannya;

5. Adanya penyimpangan terhadap budaya nyata atau budaya ideal.Budaya ideal disini adalah seluruh peraturan hukum yang berlaku dalam suatu kelompok masyarkat. Namun, dari kenyataannya, tidak orang yang patuh dari seluruh peraturan resmi. Antara budaya nyata dan budaya ideal selalu bisa saja terjadi kesenjangan. Artinya, peraturan yang telah menjadi pengetahuan umum di kehidupan sehari-hari yang cenderung banyak dilanggar;

6. Adanya aturan atau norma-norma penghindaran dalam penyimpangan sosial Jika suatu masyarakat terdapat nilai atau norma yang melarang suatu perbuatan ingin sekali diperbuat oleh banyak orang, akan muncul norma-norma penghindaran. Norma penghindaran adalah pola perbuatan yang dilakukan orang untuk memenuhi keinginan mereka tanpa harus dengan menentang nilai-nilai dengan tata kelakuan secara terbuka. Jadi, norma-norma yang sifatnya setengah melembaga (semi institutionalized).

7. Penyimpangan sosial bersifat adaptif (menyesuaikan) Penyimpangan sosial tidak selalu sebagai ancaman karena biasanya dianggp sebagai alat pemelihara ketenangan atau ketentraman sosial. Di satu pihak, masyarakat memerlukan keteraturan dan kepastian dalam kehidupan.

Dari persoalan diatas, akan memberikan dampak social yang perlu dicarikan pemecahannya, idealnya mahasiswa senantiasa memiliki perilaku yang lebih akadmis dan nilai-nilai kesopanan dan norma social semestinya di terapkan dalam kehanidupan kampus. Karena dosen memiliki otoritas untuk menentukan tingkat kelulusan dan nilai mahasiswa.

Sebagai makhluk social, manusia tidak akan lepas dari proses sosialisasi. Manusia akan selalu memerlukan oranglain. Sekaya dan sekuat apapun, manusia tidak akan bisa hidup tanpa orang lain di sekitarnya. Karena itu, kebutuhan manusia akan sosialisasi memang sangat penting, sepenting kebutuhan manusia akan makan dan minum.Langkah preventif dalam terjadi perilaku penyimpangan sosial dilakukan seseorang agar tidak beradadalam penyimpangan sosial yang lebih merugikan atau bersifat negatif.Faktor-faktor pencegahan dalam perilaku penyimpangan sosial adalah sebagai berikut.

Pertama, faktor dari keluarga. Adapun Upaya preventif untuk penyimpangan sosial dalam faktor keluarga adalah merupakan awal dari proses sosialisasi dalam pembentukan kepribadian seseorang. Kepribadian seseorang mulai terbentuk dengan baik jika lahir dan tumbuh berkembang dengan lingkungan keluarga yang baik, begitu juga dengan sebaliknya.

Kedua, faktor sekolah.Pencegahan penyimpangan sosial dalam faktor sekolah dapat dilakukan mengingat di sekolah tersebut adalah tempat menimba ilmu yang memberikan pendidikan moral selain dari pendidikan umum.

Ketiga, faktor eksternal yaitu lingkungan dan teman: Pencegahan penyimpangan sosial dalam faktor lingkungan dan teman adalah tempat yang sangat mempengaruhi watak seseorang karna dalam pergaulan seseorang dituntut agar dapat berdaptasi/menyesuaikan diri dengan lingkungan tempat tinggal dan temannya.

Keempat, faktor dari media massa. Pencegahan penyimpangan sosial dalam faktor media massa adalah suatu wadah sosialisasi yang mempengaruhi kehidupan seseorang. Artinya edukasi bisa juga terjadi melalui tontonan yang bermutu dari media massa. Maka setiap orang harus dapat memilah media massa yang berisi informasi yang baik dan bersifat positif untuk terhindari dari penyimpangan sosial.

Fenomena anak jalanan di Jambi ini jelas membuktikan sebuah fakta bahwa tidak terpenuhinya hak-hak anak baik oleh orang tua, masyarakat, maupun negara.

Disisi lain, tersedianya berbagai macam jenis pekerjaan dan sektor informal di kota membuat kehidupan kota lebih bervariasi dari sudut jenis pekerjaan yang tersedia. Inilah salah satu faktor yang membuat setiap orang termasuk para anak yang seyogiyanya bersekolah malah tertarik untuk mencari nafkah, dan yang paling menarik lagi adalah di kota-kota, jenis pekerajan untuk seusia remaja juga tersedia banyak. Inilah sebabnya mengapa anak jalanan lebih sering dijumpai di kota daripada di desa.

Jika diperhatikan, tempat-tempat anak jalanan tersebut sangat berbahaya. Selain mengganggu ketertiban dan kenyamanan orang lain, juga dapat membahayakan dirinya sendiri dan memberi peluang untuk tindak kekerasan. Bahkan anak jalanan itu sendiri berpotensi menjadi kriminil seperti mengompas teman-temanya atau orang lain yang lebih lemah, pencurian kecil-kecilan, dan pemakaian bahkan perdagangan obat-obatan terlarang.

\section{METODE}

\section{Pendekatan Penelitian}

Pendekatan penelitian yang diterapkan dalam tulisan ini yaitu pendekatan kualitatif, yang secara spesifik bercorak yuridis-empiris. Pendekatan kualitatif adalah cara menghampiri permasalahan penelitian dengan kajian secara komprehensif dan holistic yang mana kemudian hasil kajian itu dituangkan dalam bentuk narasi deskriptif 
secara objektif dengan tambahan analisis pribadi dalam perspektif yuridis atas persoalan anak punk jalanan yang telah terjadi secara empris. ${ }^{6}$

\section{Batasan Penelitian}

Tulisan ini difokuskan untuk menjawab dua hal utama, yaitu: (a) Apakah yang menjadi faktor penyebab munculnya anak punk jalanan di Jambi? (b) Apakah tindak pidana yang dilakukan anak punk jalanan?

\section{Sumber dan Jenis Data}

Sumber data untuk tulisan ini berasal dari literatur tertulis (buku, jurnal, artikel, dan sebagainya).Adapun jenis datanya dibagi dua jenis, yaitu primer dan sekunder.Jenis data primer adalah data terkait yang berhasil dihimpun oleh penulis secara pribadi. ${ }^{7}$ Sumber-sumber datanya diambil dari beberapa literature yang relevan.

Jenis data dibagi kepada dua bagian, yaitu: data primer dan data sekunder. Data primer adalah data yang diperoleh secara langsung dari objek penelitian. ${ }^{8}$ Yang menjadi data primer penelitian ini adalah sejumlah literature yang terkait langsung dengan pemaparan tentang lingkungan menurut hukum pidana.

Kemudian, data sekunder adalah data yang ada dalam pustaka atau data dari tangan kedua atau data yang bukan diusahakan sendiri pengumpulanya oleh peneliti. ${ }^{9}$ Data sekunder penelitian ini adalah literatur yang tidak langsung berkenaan dengan isu-isu lingkungan menurut hukum pidana dan filsafat moral, akan tetapi bersifat menunjang untuk digunakan sebagai informasi tambahan.

\section{Teknik Pengumpulan Data}

Teknik pengumpulan data tulisan ini yaitu dokumentasi. Dokumentasi adalah cara mengumpulkan data melalui tulisan, seperti arsip-arsip, dan termasuk juga buku-buku tentang pendapat, teori, atau hukum-hukum dan lain-lain yang berhubungan dengan masalah penelitian. ${ }^{10}$

\section{Teknik Analisis Data}

Teknik analisis data yang dipakai dalam tulisan ini adalah content analysis: yaitu pembahasan mendalam terhadap isi suatu permasalahan. ${ }^{11} \mathrm{Jadi}$ dalam tulisan ini, dilakukan pemabahasan yang mendalam dan cermat dari setiap literature yang membahas tentang isu lingkungan dalam konteks hukum pidana dan filsafat moral.Kemudian, hasil pencermatan tersebut disusun secara sistematis dalam tulisan jurnal ini.

\section{Definisi Operasional Penelitian}

Definisi operasional dalam tulisan ini disusun agar tidak menimbulkan makna konotatif dari setiap variable judul tulisan ini.Sehingga antara penulis dan pembaca terdapat persamaan lingua franca.Adapun definisi operasionalnya adalah sebagai berikut:

\section{Konsep tentang Anak}

Menurut Desy Anwar, remaja adalah mulai dewasa, sudah sampai umur untuk kawin, atau bisa juga dikatakan sebagai usia muda. ${ }^{12}$ Remaja sebagai periode tertentu dari kehidupan manusia merupakan suatu konsep yang relatif baru dalam kajian psikologi. Di negara-negara barat, istilah remaja di kenal dengan "adolensence" (kata benda adolescentia $=$ remaja $)$, yang berarti tumbuh menjadi dewasa atau dalam perkembangan menjadi dewasa. Dalam perkembanganya, istilah adolescence sesungguhnya memiliki arti yang luas, mencakup kematangan mental, emosional, sosial dan fisik. Remaja adalah satu usia dimana individu menjadi terintegrasi kedalam masyarakat dewasa. Suatu usia dimana anak tidak merasa bahwa dirinya berada dibawah tingkat orang yang lebih tua melainkan merasa sama, atau paling tidak sejajar. ${ }^{13}$

Hukum rekapitulasi berpendapat bahwa:"Perkembangan psikis individu merupakan pengulangan urut-urutan tingkah laku dari perkembangan nenek moyang satu bangsa. Jadi sesuai dengan hukum rekapitulasi, ada semacam prilaku kolektif atau meminjam istilah Carl Gustav Jung adalah semacam ketidaksadaran kolektif."14Berdasarkan

\footnotetext{
${ }^{6}$ Sugiyono, Memahami Penelitian Kualitatif, (Bandung: Alfabeta, 2014), hlm. 1

${ }^{7}$ Rosady Ruslan, Metode Penelitian: Public Relation dan Komunikasi, (Jakarta: Grafindo Persada, 2003), hlm. 23-24

${ }^{8}$ Rosady Ruslan, Metode Penelitian: Publik Relation dan Komunikasi, (Jakarta: Grafindo Persada, 2003), hlm. 23-24

${ }^{9}$ Ibid., hlm. 29

${ }^{10}$ Suharsimi Arikunto, Manajemen Penelitian (Jakarta: P21PTK, 1993), hal. 202 lihat pula Sanafiah Faisal, Penelitian
} Kualitatif Dasar-dasar dan Aplikasi (Malang: Yayasan Asih Asuh, 1990), hlm. 46

${ }^{11}$ http:www.researchgate.net

${ }^{12}$ Desy Anwar, Kamus Lengkap Bahasa Indonesia (Surabaya: Amelia, 2003), hlm. 360

${ }^{13}$ Abu Ahmadi dan Munawar Soleh, Psikologi Perkembangan (Jakarta: Rineka Cipta, 2005), hlm. 121

${ }^{14}$ Ibid., hlm. 25 
hukum rekapitulasi ini, perkembangan individu dapat digolongkan kedalam beberapa fase atau masa yang dalam bentuk riilnya dapat kita lihat dari permainan mereka. Adapun fase-fase itu adalah sebagai berikut:

1. Fase berburu dan menyamun (sampai dengan 8 tahun). Ciri-ciri yang menonjol pada masa ini adalah bahwa anakanak dalam permainanya menunjukkan kesenangan menangkap binatang, bermain dengan panah-panahan, membuat rumah-rumahan, saling mengintai, saling memata-matai, saling menyelinap untuk menangkap musuh dan sebagainya.

2. Fase beternak (8-10 tahun). Masa ini disebut juga masa menggembala. Cara yang menonjol pada masa ini adalah anak senang sekali memelihara binatang. Misalnya memlihara ayam, merpati, perkutu, kucing, dan sebagainya.

3. Fase bertani (10-12 tahun). Cirri yang mononjol pada masa ini adalah perhatian anak tertuju pada kegemaran memelihara tanaman seperti misalnya, tanaman bunga, biasanya anak ingin mempunyai kebun sendiri meskipun dalam ukuran mini.

4. Fase berdagang (12-14 tahun). Ciri yang menonjol pada masa ini adalah bahwa perhatian anak tertuju kepada hal perdagangan. Misalnya bermain jual beli, tukar menukar perangko bekas, pengumpulan bungkus rokok dan sebagainya.

5. Fase industri (15 tahun ke atas). Ciri yang mononjol pada masa ini adalah anak gemar membuat permainanya sendiri dengan bahan-bahan yang ada disekelilingnya.misalnya membuat laying-layang, seruling bambu, ketapel, gasing dan sebagainya. ${ }^{15}$

\section{Konsep tentang Anak Punk Jalanan}

Kata punk arti sebenarnya adalah busuk, kemudian mengalami pergeseran makna diakhir masa kontemporer ini menjadi makna seolah "positif". Sementara kata sifat funky diterapkan pada suatu yang berkaitan dengan black musik hingga ke soul food. Sedangkan dibidang gaya berkaitan dan cara berdandan, penerapan istilah punky merujuk pada suatufenomena mode/gaya yang lahir diawal 1970-an yang disebut Pimp Look yang muncul disekitar perkampungan kumuh orang kulit hitam (ghetto) Amerika.

Punk sebagai remaja yang masih mencari identitas tentunya juga tidak terlepas dari pengaruh teman-teman sebaya (peer).Seorang remaja yang memilih untuk masuk ke dalam komunitas punk dapat saja dikarenakan oleh pengaruh teman-temannya, keadaan teman-teman yang lebih memiliki kelekatan yang lebih tinggi ketimbang kelekatan dengan orang tua tentunya menjadi faktor mengapa seorang anak memilih untuk memasuki komunitas Punk.

Komunitas yang satu ini memang sangat berbeda sendiri dibandingkan dengan komunitas pada umumnya.Banyak orang yang menilai bahwa komunitas yang satu ini termasuk salah satu komuitas yang urakan. Dalam "Pholisophy Of Punk", Craing O'hara menyebutkan tiga pengertian Punk:

1. Anak jalanan/Punk sebagai tren remaja dalam fashion dan musik

2. Anak jalanan/Punk sebagai pemula yang punya keberanian memberontak, memperjuangkan kebebasan dan melakukan perubahan

3. Anak jalanan/Punk sebagai bentuk perlawanan yang hebat karena menciptakan musik, gaya hidup, komunitas dan kebudayaan sendiri. ${ }^{16}$

4. Anak jalanan/punk merasa menemukan konsep dan pemikiran mereka terhadap gaya unik dan khas yang ditonjolkan oleh punk. Komunitas punk di Indonesia sangat diwarnai oleh budaya dari barat atau Amerika dan Eropa. Biasanya perilaku mereka terlihat dari gaya busana yang mereka kenakan seperti sepatu boots, potongan rambut mohawk ala suku Indian, atau dipotong ala feathercut dan diwarnai dengan warna-warna yang terang, rantai dan spike, jaket kulit, celana jeans ketat dan baju yang lusuh, anti kemapanan, anti sosial, kaum perusuh dan kriminal dari kelas rendah, pemabuk berbahaya sehingga banyak yang mengira bahwa orang yang berpenampilan

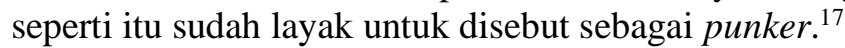

\section{HASIL DAN PEMABAHASAN}

\section{Faktor Penyebab Munculnya Anak Jalanan di Jambi \\ Faktor Internal}

Adapun dalam analisa peneliti, yang menjad fakor penyebab perilaku menyimpang dalam faktor internal adalah intelegensi atau tingkat kecerdasan, usia, jenis kelamin dan kedudukan seseorang dalam keluarga. Contohnya: seseorang yang tidak normal dan pertambahan usia.

Hidup menjadi anak jalananbukanlah pilihan hidup yang menyenangkan, melainkan keterpaksaan yang harus mereka terima karena adanya faktor-faktor tertentu.Anak jalanan, bagaimanapun telah menjadi fenomena yang menuntut perhatian banyak kalangan. Secara psikoligis mereka adalah anak-anak yang pada tahap tertentu belum

\footnotetext{
${ }^{15}$ Muhammad Ali dan Muhammad Asrori, Psikologi Remaja (Jakarta: Bumi Aksara, 2005), hlm. 13-14

${ }^{16}$ O. Hara Craing, Philosophy of Punk: More Than Noise (London Edinburgh San Francisco: AK. Press, 2004), hlm 32

${ }^{17}$ G. Marshall, Skinhead Nation: Truth About The Skinhead Cult (London: Dunnon, 2005), hlm. 28
} 
mempunyai bentukan mental emosional yang kokoh, sementara pada saat yang sama mereka harus bergelut dengan dunia jalanan yang keras dan cenderung berpengaruh buruk bagi perkembangan dan pembentukan kepribadianya.

Aspek psiklogis ini berdampak kuat pada aspek sosial, dimana labilitas emosi dan mental mereka yang ditambah lagi dengan penampilan mereka yang kumuh, melahirkan pencitraan negataif oleh sebahagian masyarakat terhadap anak jalanan yang diidentikkan dengan pembuat onar, anak-anak kumuh, suka mencuri, bahkan ada yang menilai mereka sebagai sampah masyarakat yang harus disingkirkan. ${ }^{18}$

Secara psikologis, yang menjadi faktor muculnya prilaku ataupun fenomena anak jalanan dalam kehidupan remaja adalah sebuah gejala yang diistilahkan oleh Kartono dan Gulo sebagai "kompensasi." Kompensasi yang dilakukan para anak jalananmerupakan bentuk kompensasi negatif karena merupakan bagian dari rasa frustasi untuk mengekspresikan kemarahan subjek (anak jalanan) kompensasi merupakan mekanisme pembelaan diri dimana seorang individu mengganti suatu aktivitas dengan aktivitas lainya untuk memuaskan kegagalan-kegagalanya, biasanya hal ini secara tidak langsung menyatakan kegagalan dan hilangnya kepercayaan diri dalam melakukan suatu aktivitas, dan sebagai pelariannya anak jalanan itu kemudian melakukan aktivitas menyimpang sebagai jalan keluar dari persoalan yang menimpa diri mereka. ${ }^{19}$

Sedangkan menurut O' Hara, beliau mengamati bahwa sesungguhnya teori "kenyamanan" lah yang menyebabkan merebaknya anak jalanan di seluruh dunia. (dalam hal ini bisa dikaitkan dengan eksistensi anak jalanan di Jambi, menurut penulis). Perasaan kenyamanan yang dirasakan anak jalanan di Jambi akhirnya membuat mereka semakin menikmati dirinya sebagai anak jalanan. Mereka semakin terlibat dengan pergaulan di dunia anak jalanan, dengan segala atribut dan simbol yang ditunjukkan.Pola pikir mereka pun ikut terbawa dalam dunia anak jalanan.Mereka merasa bahwa anak jalanan adalah satu pilihan yang tepat bagi dirinya. ${ }^{20}$

Ketika penulis mewawancarai salah seorang anak jalanan di Terminal Rawasari, kota Jambi, terkait dengan motivasi dia menjadi anak jalanan, Ia menuturkan pendapatnya sebagai berikut:

"Terus terang saja bang, saya tidak lagi merasa nyaman untuk tetap tinggal dirumah. Dirumah saya merasa dikekang, tidak diberi ruang untuk bebas.Sedangkan disini saya justeru merasa nyaman.Mau apapun saja boleh, $n g g a k$ ada yang ngelarang.Disini dengan temen-temen, saya merasa nyaman, tiap malam kami gitaran, nyanyinyani, ngamen, pokoknya bebas mau ngapain lah bang." 21

Pada kesempatan lainya, penulis mewawancarai Ibu Jamilah, salah seorang kader LSM yang bergerak dibidang sosial, ketika ditanyai pendapatnya mengenai faktor penyebab banyaknya anak jalanandikota Jambi ini, beliau mengemukakan pendapatnya sebagai berikut:

"Anak jalananinimerasa menemukan konsep dan pemikiran mereka terhadap gaya unik dan khas yang dimunculkan oleh mereka sendiri.Komunitas anak jalanan di Jambi ini sangat pengaruhi olehbudaya asing.Tampilan mereka ini secara umum tampak kumal tidak bersih, bau, dan tidak terurus.Rambut dibuat model tidak karu-karuan dan semua penampilan mereka sangat jauh dari norma-norma kesopanan, kalau kita lihat bahkan sangat jelas-jelas membuka aurat." 22

Di lain kesempatan, penulis melakukan wawancara dengan salah satu remaja anak jalanan dikawasan los perbelanjaan pasar arah ke mini market Mandala. Ketika ditanyai alasan mereka melakukan aktivitas dan merubah status sosial mereka menjadi anak jalanan, mereka menjawab dengan alasan sebagai berikut:

"Kami ini bang menjadi anak jalanan ingin mencari jati diri bae, soalnyo kami ini maunyo tu diakui keberadaan kami ini. Kami cuma mau supaya orang lain tahu dan kenal sama kami. Lagi pulo bang, dengan menjadi anak jalanan banyak orang yang jadi segan samo kami. Mungkin karno ngleiat tampilan kami yang seram kali yo bang. Disamping itu, kami jugo senang dengan jadi anak jalanankami bebas kumpul-kumpul samo kawan anak jalanan yang lain." 23

Penulis juga mewawancarai remaja anak jalanan yang seringkali berkeliaran di daerah Kambang atau disekitar kompleks perkantoran Gubernur kota Jambi. Penulis sengaja melakukan wawancara demi untuk mengetahui apa

\footnotetext{
${ }^{18}$ Wawancara dengan Ibu Rita, pegawai Dinas Sosial Provinisi Jambi pada tanggal 2 Agustus 2020

${ }^{19}$ Kartono dan Gulo, Kamus Psikologi (Bandung: Pionie Jaya, 1987), hlm. 78

${ }^{20}$ O' Hara, The Philosophy of Punk: More Than Noise. Secound edition (San Fransisco: AK. Press, 1999), hlm. 41

${ }^{21}$ Wawancara dengan Rojak, salah satu street punker di Terminal Rawasari kota Jambi pada tanggal 5 Juli 2020

${ }^{22}$ Wawancara dengan Ibu Jamilah salah seorang akader LSM bidang sosial pada tanggal 5 Juli 2020

${ }^{23}$ Wawancara dengan Dul, Apet dan Rudin, mereka adalah salah satu kelopok street punk yang acapkali mangkal di daerah pasar los gang Mandala. Wawancara ini berlangsung pada tanggal 09 Juli 2020
} 
motivasi mereka mengikuti gaya hidup anak jalanan tersebut. Dan setelah ditanya, jawaban mereka adalah sebagai berikut:

"Sejujurnya bang, kami memasuki dunia anak jalanan ini dengan niat untuk mengurangi beban orang tua gua di Jakarta bang. Keluarga gua itu, boleh dikata masuk kriteria miskin lah bang. Jadi daripada saya cuma jadi beban hidup ortu gua kan lebih baik gua kayak gini bang. ${ }^{24}$

Berdasarkan kepada fakta yang terungkap dalam sesi wawancara yang telah penulis lakukan terhadap beberapa remaja anak jalanan di kota Jambi ini penulispun akhirnya menyadari akan adanya korelasi antara pernyataan atau jawaban para remaja anak jalanan di kota Jambi ini dengan teori yang dikemukan oleh UNICEF mengenai remaja anak jalanan tersebut.

Studi yang dilakukan UNICEF pada remaja yang dikategorikan remaja anak jalanan menunjukkan bahwa motivasi mereka hidup dijalanan bukanlah sekedar karena desakan kebutuhan ekonomi rumah tangga, melainkan juga karena terjadinya kekerasan dan keretakan kehidupan rumah tangga orang tuanya. Bagi remaja anak jalanan ini, kendati kehidupan dijalanan tidak kalah keras, namun bagaimanapun dinilai lebih memberikan alternatif dibandingkan dengan hidup dalam keluarganya yang penuh dengan kekerasan yang tidak dapat mereka hindari. Meski tidak selalu terjadi, tetapi acap ditemui bahwa latar belakang anak-anak memilih hidup dijalanan adalah karena kasus-kasus tindakan yang salah pada anak. ${ }^{25}$

\section{Faktor Eksternal}

Penyebab perilaku menyimpang dalam faktor eksternal adalah kehidupan rumah tangga, atau keluarga, pendidikan di sekolah, pergaulan dan media massa. Contohnya: seorang anak yang biasa melihat orang tuanya bertengkar dapat melarikan diri pada obat-obatan, atau narkoba. Pergaulan individu yang berhubungan dengan temantemannya, media massa, media cetak, media eletkronik.

Menjelaskan sebab terjadinya perilaku menyimpang ada kaitannya dengan sosialisasi yang kurang tepat.Individu tidak dapat menyerap norma-norma kultural budayanya atau individu yang menyimpang harus belajar bagaimana melakukan penyimpangan.

Bisa jadi anak jalanan tidak tahu menahu tentang apa yang mereka lakukan menyimpang apa tidak karena itu perlu di beri pengetahuan tentang perilaku yang mereka lakukan. Dimana yang penting bagi mereka mendapatkan uang untuk keperluan hidup mereka Menurut Reza adalah seperti berikut ini:

"Bahwa saya berada di jalanan sejak umur 9 tahun, sekarang sudah berumur 11 tahun, jadi selama 2 tahun berada di jalanan. Dan orang tua saya yang menyuruh saya untuk menjual Koran di lampu merah. Simpang Pulai dari jam 09.00 WIB sampai dengan jam 16.00 WIB. Adapun penghasilan saya ro ribu/ perhari."26

Dari wawancara diatas tergambar bahwa apa yang dilakukan oleh anak tersebut, dia hanya menjalankan apa yang di suruh oleh orang tuanya, tanpa harus berani melawan atau menolak suruhan tersebut.

\section{Bentuk Tindak Pidana Kriminal yang Dilakukan Anak Jalanan}

Adapun penyimpangan Sosial Primer: Pengertian penyimpangan sosial primer adalah penyimpangan yang bersifat sementara (temporer). Orang yang melakukannya masih tetap dapat diterima oleh kelompok sosialnya karena tidak terus menerus melanggar aturan.Seperti biasanya melanggar rambu lalu lintas atau pernah meminum minuman keras di suatu pesta.

Kemudian, bentuk penyimapangan Sosial Sekunder: Pengertian penyimpangan sosial sekunder adalah penyimpangan sosial yang dilakukan oleh pelakunya secara terus menerus walaupuntelah diberikan sanksi-sanksi. Oleh karena itu, setiap pelaku secara umum dikenal sebagai orang yang berperilaku menyimpang. Seperti, seseorang yang setiap hari minum-minuman keras.

Penyimpangan Individu: Pengertian penyimpangan individu adalah penyimpangan yang dilakukan sendiri tanpa dengan orang lain. Hanya satu individu saja yang melakukan belawanan dengan norma-norma yang berlaku.

Salah seorang informan mengatakan penjelasannya kepada peneliti sebagai berikut:

\footnotetext{
${ }^{24}$ Wawancara dengan Pepenk, remaja street punk yang sering mangkal di kompleks perkantoran gubernur kota Jambi pada tanggal 10 Agustus 2020

${ }^{25}$ Suyanto Bagong dan Haridi, Sri Sanituti, Krisis dan Child Abuse, Kajian Sosiologis Tentang Kasus Pelanggaran Hak dan Anak-anak yang Membutuhkan Perlindungan Khusus (Surabaya: Airlangga, 1999), hlm. 46

${ }^{26}$ Anak Jalanan, Reza, wawancara dengan peneliti, 05 Agustus 2020
} 
"Saya ada di sini (simpang 4 telanapura kantor Gubernur) dari jam 2 siang sampai jam 5 sore, sebelum masuk sekolah dasar, atas kemauan sendiri- berjualan Koran. Hasil jualan dapat Rp. 8.000/H."27

Kemudian, informan lain memberikan keterangan sebagai berikut:

"Sejak kecil sudah berada dijalanan, jual Koran kadang juga mengemis, kemauan sendiri dan ingin bantu orang tua dan biaya sekolah, hasil sekitar Rp. 50.000/H. Pulang dari sekolah jam 1 s/d 4 di lampu merah broni." 28

Dari wawacara diatas, dapat dikatakan bahwa anak jalanan melakukan aktivitas di lampu merah karena kemauan sendiri (invidu) artinya tidak perintah oleh orang lain atau disuruh oleh orang tua mereka. Adapun kita saksikan di lampu merah ada 2 dan 3 bahkan lebih dari simpang lampu merah, itu karena factor kebetulan saja mereka bersamaan, mamun tidak ada kesepakatan atau perundingan untuk bertemu, jika di saksikan, maka tidak mungkin mereka harus berkelompok, karena mereka saling meperebutkan sumberdaya. Dan kehidupan mereka individualis dan hasil yang mereka dapatkan untuk mereka sendiri.Tidak untuk dibagi ke teman atau sesamanya.Jadi penyimpangan yang dilakaukan anak jalan boleh dikatakan bersifat individu.

Penyimpangan Bersifat Positif: Pengertian penyimpangan bersifat positif adalah penyimpangan sosial yang memiliki dampak positif terhadap sistem sosial karena dianggap ideal dalam masyarakat. Anak Jalanan jika di amati, jenis penyimpangan bersifat positif. Sebagaimana ungkapan anak jalanan Kadir berikut ini:

"Sejak 4 tahun yang lalu, saya men jual Koran dan mencari nafkah untuk keluarga, hasil yang didapat dari menjual Koran Rp. 50.000 - Rp.60.000 /H dari jam 08.00- 18.00 WIB. Saya berada di sini, lampu mereh Telanaipura Simpang 4 kantor Gubernur, sejak kelas 3 sd atas kemauan sendiri, hasil jual Koran saya mendapatkan Rp. 30.000/H , pulang sekolah dari Jambi 14. $00-17.00$ WIB.”29

Kemudian, informan lain menyampaikan pendapatnya kepada peneliti sebagai berikut:

"Saya jual Koran sejak kelas 1 sd untuk menabung, sehabis sekolah saya jual Koran, dan saya dapat jual Koran Rp. 30.000/H . Sering jualan di Simpang 4 Telanaipura." 30

Dari wawancara diatas, dapat katakana bahwa anak jalan tersebut, hidup di lampu merah untuk membantu keluarga mencari nafkah dan untuk menabung.Jadi penyimpangan yang dilakukan oleh mereka tidak dikatagorikan penyimpangan yang bersifat negatif, masih pada tarap penyimpangan positif. Terbukti dari hasil temuan mereka melakukan aktivitas kehabis sekolah dan untuk keperluan membantu kehidupan rumah tangga mereka.

Menurut James W. Van Der Zanden Faktor-faktor penyimpangan sosial adalah sosialisasi sub kebudayaan yang menyimpang. Perilaku menyimpang terjadi pada masyarakat yang memiliki nilai-nilai sub kebudayaan yang penyimpang, yaitu suatu kebudayaan khusus yang normanya bertentangan dengan norma-norma budaya yang dominan/pada umumnya. Contohnya yaitu, masyarakat yang tinggal di lingkungan kumuh, masalah etika dan estetika kurang diperhatikan, karena umumnya mereka sibuk dengan usaha memenuhi kebutuhan hidup yang pokok (makan), sering cekcok, mengeluarkan kata-kata kotor, buang sampah sembarangan dan lain sebagainya. Hal itu oleh masyarakat umum dianggap perilaku menyimpang.

Anak jalanan ada juga kita jumpai yang mengeluarkan kata-kata kotor, jika mereka tidak di kasi uang padahal mereka sudah melakukan kegiatan yang menurut mereka sudah layak dikasihi, seperti aktivitas mengamen dan membersihkan mobil, namun tidak semua pengguna jalan memberikan uang.saat tidak memberikan uang, maka ketika itu anak jalanan bisa mengeluarkan kata-kata kotor seperti: pelit, dan kadang bertiak hei, oii, dan lain-lain. Seperti yang ungkapkan oleh Supardi berikut ini:

"Saya pernah dilampu merah tanpa saya suruh anak tersbut membesihkan mobil saya, tapi saya tidak memberikan uang, anak tersebut meneriaki saya ooii." 31

Berdasarkan wawancara di atas, sebenarnya dapat diketahui bahwa penyimpangan individual merupakan penyimpangan yang dilakukan oleh seseorang yang berupa pelanggaran terhadap norma-norma suatu kebudayaan

\footnotetext{
${ }^{27}$ Anak Jalanan, Febri, wawancara dengan peneliti, 01 Agustus 2020

${ }^{28}$ Anak Jalanan, Andriano Saputera, wawancara dengan peneliti, 02 Juli 2020

${ }^{29}$ Anak Jalanan, Kadir, wawancara dengan peneliti, 03 Juli 2020

${ }^{30}$ Anak Jalanan, Heri, wawancara dengan peneliti, 04 Agustus 2020

${ }^{31}$ Masyarakat Kota Jambi, Supardi, wawancara dengan peneliti, 04 Juli 2020
} 
yang telah mapan tersebut.Sehingga, penyimpangan ini disebabkan oleh kelainan jiwa seseorang dan tidak adanya kesadaran diri yang lurus atau karena perilaku yang jahat/tindak kriminalitas.

\section{SIMPULAN}

Adapun kesimpulan tulisan ini adalah sebagai berikut:

1. Faktor penyebab banyaknya anak jalanan di kota Jambi adalah dikarenakan tidak terpenuhinya kebutuhan fisik dan psikis anak, kemudian, karena keinginan pribadi dari anak jalanan itu sendiri dan faktor lingkungan.

2. Dampak persoalan pidana yang dapat mengarah kepada tindakan kriminal dari adanya anak jalanan adalah: munculnya problematika sosial baru, terganggunya ketertiban kota, narkoba, minuman keras, dan mengancam keselamatan dan keamanan warga masyarakat disekitarnya.

\section{DAFTAR PUSTAKA}

Ahmadi, Abu dan Munawar Soleh, Psikologi Perkembangan.Jakarta: Rineka Cipta, 2005

Ali, Muhammad dan Muhammad Asrori.Psikologi Remaja.Jakarta: Bumi Aksara, 2005

Anwar,Desy.Kamus Lengkap Bahasa Indonesia. Surabaya: Amelia, 2003

Arikunto, Suharsimi. Manajemen Penelitian.Jakarta: P21PTK, 1993

Bagong, Suyanto dan Haridi, Sri Sanituti, Krisis dan Child Abuse, Kajian Sosiologis Tentang Kasus Pelanggaran Hak dan Anak-anak yang Membutuhkan Perlindungan Khusus. Surabaya: Airlangga, 1999

Data statistik kota Jambi. Data tersebut penulis peroleh berdasarkan hasil wawancara penulis dengan petugas BPPS, Bapak Rahmat pada tanggal 15 Juli 2020

Faisal,Sanafiah.Penelitian Kualitatif Dasar-dasar dan Aplikasi.Malang: Yayasan Asih Asuh, 1990

Hara O.Philosophy of Punk: More Than Noise.London Edinburgh San Francisco: AK. Press, 2004

Hara,O’ The Philosophy of Punk: More Than Noise. Secound Edition. San Fransisco: AK. Press, 1999

http: //yayasan - kksp . blogspot. com / 2007 / 08 / anak-jalanan-harus-diberi-pendidikan.html. Diakses pada tanggal 10 Juli 2020 pada pukul 14:00 WIB

http:www.researchgate.net

Kartono dan Gulo.Kamus Psikologi.Bandung: Pionie Jaya, 1987

Marshall,G. Skinhead Nation: Truth About The Skinhead Cult.London: Dunnon, 2005

Ruslan, Rosady. Metode Penelitian: Public Relation dan Komunikasi.Jakarta: Grafindo Persada, 2003

Soekanto, Soerjono. Sosiologi Suatu Pengantar.Jakarta: Raja Grafindo, 1988

Stanlen D. Eitzen, Social Problems. Sydney: Allyn and Bacon Inc, 1986

Sugiyono. Memahami Penelitian Kualitatif. Bandung: Alfabeta, 2014 